Proceedings of the XXIII Conference on Applied Crystallography, Krynica Zdrój, Poland, September 20-24, 2015

\title{
Microstructure and Texture Evolution in the Welded Semi-Austenitic PH Steel after the Heat Treatment
}

\author{
A. ZiewieC*, M. Witkowska And A. ZielińskA-LipieC \\ AGH University of Science and Technology, Faculty of Metals Engineering and Industrial Computer Science, \\ al. A. Mickiewicza 30, 30-059 Krakow, Poland
}

\begin{abstract}
The aim of this study was to reveal the influence of the heat treatment after welding of 17-7PH (X7CrNiAl17-7) steel on the microstructure evolution and the texture of the welds. Microstructure investigation carried out by light microscopy and transmission electron microscopy showed that the austenite and $\delta$ ferrite coexist in as-welded condition. Annealing at the temperature range between $400{ }^{\circ} \mathrm{C}$ and $620^{\circ} \mathrm{C}$ after welding causes small changes in the microstructure and the hardness of the welds increases. Heat treatment at $760^{\circ} \mathrm{C}$ for $1 \mathrm{~h}$ resulted in the partial destabilization of the austenite. Aging after destabilization leads to tempering of the martensite: first the hardness increases and then decreases. The maximum hardness is observed when the ageing temperature reaches $510{ }^{\circ} \mathrm{C}$. XRD studies confirmed the presence of the two phases: $\delta$ ferrite and austenite. Annealing at $400{ }^{\circ} \mathrm{C} / 1 \mathrm{~h}$ and $550^{\circ} \mathrm{C} / 1 \mathrm{~h}$ results in changes of the intensities for individual peaks derived from austenite and ferrite. The calculated ratios of peak intensity were compared with the intensities of the reference sample. The differences in intensities suggested strong texture of the material.
\end{abstract}

DOI: 10.12693/APhysPolA.130.956

PACS/topics: 81.20.Vj, 81.40.Gh, 81.40.Ef, 68.37.Lp

\section{Introduction}

Semi-austenitic steels are a group of the precipitation hardened stainless steels with the $M_{s}$ (martensite start temperature) below $0^{\circ} \mathrm{C}$. At room temperature these steels are austenitic. Cold working treatment at a temperature $c a .-75{ }^{\circ} \mathrm{C}$ or thermal destabilization of the austenite involving heating to a temperature range of $700-800^{\circ} \mathrm{C}$ allows the martensitic transformation. The final treatment is ageing. Semi-austenitic PH stainless steels are widely applied in surgical instruments, pressure vessels and aerospace parts. Specific applications include securing rings, springs, membranes, bulkheads aircraft [1-5]. This group of materials include stainless steel 17-7PH (X7CrNiAl17-7). Although the steels are widely applied, former studies concentrate on cracking prevention of the steel [6] and research has been mainly focused on the influence of the heat treatment on microstructure and properties of the base material [7].

There are only a few reports on the microstructure of welded joints of semi-austenitic precipitation hardened steels $[8,9]$. Choosing the appropriate heat treatment conditions before and after welding is vital for achieving of the optimum microstructure and mechanical properties of the material. The aim of the present study was to investigate the effect of heat treatment after welding of steel $17-7 \mathrm{PH}$ to change the microstructure and texture joints.

\footnotetext{
*corresponding author; e-mail: aziewiec@agh.edu.pl
}

\section{Experimental}

The investigations were carried out on sheets of 17-7PH commercial steel. The chemical composition of the steel is given in Table I. The welds were made using autogenous gas tungsten arc welding (GTAW) method. These welded joints were cut into samples which were heat treated according to Table II. Samples numbered 2 to 6 were annealed at $400,450,510,620^{\circ} \mathrm{C}$ for $1 \mathrm{~h}$. Samples 7 to 12 were heat treated at $760^{\circ} \mathrm{C}$ for $1 \mathrm{~h}$ to destabilize austenite and then were aged at the same conditions as samples 2 to 6 . The Vickers hardness measurements were carried out using a durometer type HPO-250. Microstructure of the steel welds was carried out using light microscope Leica DMLM and transmission electron microscope JEOL 200CX.

TABLE I

Chemical composition [wt\%] (min./max.) of the 17-7PH (X7CrNiAl17-7) steel.

\begin{tabular}{c|c|c|c|c|c|c|c}
\hline \hline $\mathrm{C}$ & $\mathrm{Mn}$ & $\mathrm{P}$ & $\mathrm{S}$ & $\mathrm{Si}$ & $\mathrm{Cr}$ & $\mathrm{Ni}$ & $\mathrm{Al}$ \\
\hline 0.09 & 1.00 & 0.04 & 0.03 & 1.00 & 16 & 6.5 & 0.75 \\
$\max$. & max. & max. & max. & max. & 18 & 7.75 & 1.5
\end{tabular}

The X-ray diffraction study was made on selected samples in as-welded condition and after welding and annealing at $400^{\circ} \mathrm{C}$ and $550^{\circ} \mathrm{C}$ (samples no. 1, 2, and 5). The HZG4 diffractometer equipped with a Co lamp $\left(\lambda_{K_{\alpha}}=1.79 \AA\right)$ was used. The texture measurements were performed by the Schulz back-reflection method using the texture attachement D8 Advance Bruker. The incomplete pole figures were recorded of three planes for each of the component phases, namely: $\{111\},\{200\}$, 
TABLE II

Labeling of the heat treated samples; "+" denotes application of a given heat treatment.

\begin{tabular}{|c|c|c|c|c|c|c|c|c|c|c|c|c|}
\hline \multirow{2}{*}{$\begin{array}{c}\text { Heat } \\
\text { treatment }\end{array}$} & \multicolumn{12}{|c|}{ Sample number } \\
\hline & 1 & 2 & 3 & 4 & 5 & 6 & 7 & 8 & 9 & 10 & 11 & 12 \\
\hline Welding & + & + & + & + & + & + & + & + & + & + & + & + \\
\hline \multicolumn{13}{|c|}{ Annealing } \\
\hline $760^{\circ} \mathrm{C} / 1 \mathrm{~h}$ & - & - & - & - & - & - & + & + & + & + & + & + \\
\hline $400^{\circ} \mathrm{C} / 1 \mathrm{~h}$ & - & + & - & - & - & - & - & + & - & - & - & - \\
\hline $450^{\circ} \mathrm{C} / 1 \mathrm{~h}$ & - & - & + & - & - & - & - & - & + & - & - & - \\
\hline $510^{\circ} \mathrm{C} / 1 \mathrm{~h}$ & - & - & - & + & - & - & - & - & - & + & - & - \\
\hline $550^{\circ} \mathrm{C} / 1 \mathrm{~h}$ & - & - & - & - & + & - & - & - & - & - & + & - \\
\hline $620^{\circ} \mathrm{C} / 1 \mathrm{~h}$ & - & - & - & - & - & + & - & - & - & - & - & + \\
\hline
\end{tabular}

$\{220\}$ planes for austenite and $\{110\},\{200\},\{211\}$ for ferrite. For obtaining a three-dimensional texture representation the orientation distribution functions (ODFs) were computed from three incomplete pole figures following the series expansion method described by Bunge. The analysis of the ODFs was performed in section of $\varphi_{2}=$ const for the austenite and in section of $\varphi_{1}=$ const for the ferrite in steps of $5^{\circ}$ within the range $0-90^{\circ}$.

\section{Results and discussion}

In the as-welded state hardness of the steel 17-7 $\mathrm{PH}$ is $220 \mathrm{HV} 10$. Influence of ageing temperature on hardness is shown in Fig. 1. Ageing at $400^{\circ} \mathrm{C} / 1 \mathrm{~h}$ (sample 2 ) increases the hardness to $420 \mathrm{HV} 10$. Increase of temperature to $620^{\circ} \mathrm{C} / 1 \mathrm{~h}$ (sample 6 ) enhances hardness to $480 \mathrm{HV} 10$. Heat treatment at $760^{\circ} \mathrm{C} / 1 \mathrm{~h}$ (sample 7) increases the hardness from $220 \mathrm{HV} 10$ to $340 \mathrm{HV} 10$. The increase in hardness indicates destabilization of austenite and some fraction of the austenite transforms into martensite upon cooling. Ageing of the welds at 400, 450 , and $510^{\circ} \mathrm{C}$ after the destabilizing treatment (samples 8-10) causes a rapid increase in hardness of 510 HV10. Ageing at temperatures up to $620^{\circ} \mathrm{C}$ (samples 11 and 12) results in a gradual decrease in hardness to $390 \mathrm{HV} 10$, which is due to the overageing. A similar phenomenon is observed by Brooks in precipitation hardened martensitic stainless [10].

The microstructure of the $17-7 \mathrm{PH}$ steel in as-welded state consists of austenite and delta ferrite (Fig. 2a). TEM studies (Fig. 3) confirmed that the microstructure consists of austenite and delta ferrite. Ferrite is mostly skeletal and lathy. There are also small areas of blocky ferrite. Figure 3a shows the microstructure of the delta ferrite of the lathy morphology that is localized mainly between the laths of austenite. Kokava et al. in their work [11] explain that the lathy ferrite and austenite are oriented nearly in the Kurdiumov-Sachs (K-S) relationship, and this relationship does not exist between skeletal ferrite and austenite. Subsequent work [12] shows that other crystallographic relationships between lathy ferrite and austenite may be possible. The best known of them are those of Bain, K-S, and Nishiyama

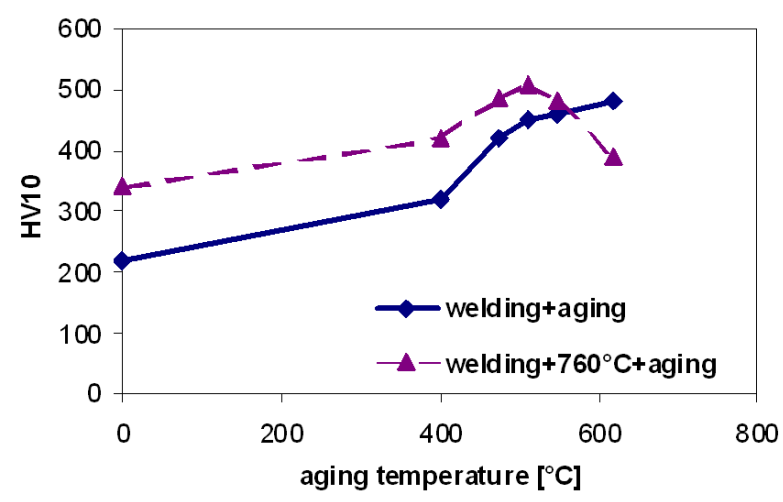

Fig. 1. Hardness of welds vs. ageing time for 17-7 PH steel.

$\mathbf{a}$

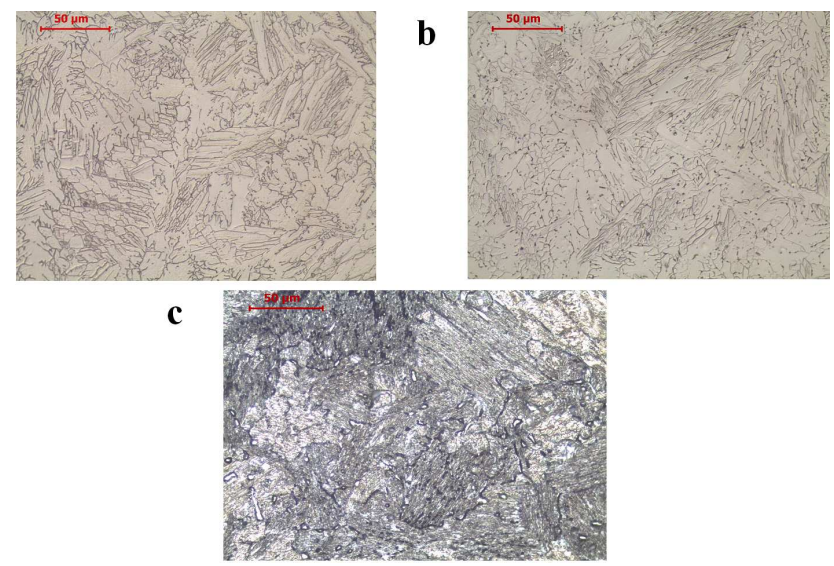

Fig. 2. LM microstructures of the 17-7PH welds: (a) microstructure in as-welded condition, (b) microstructure in as-welded condition and subsequent ageing at $465^{\circ} \mathrm{C} / 1 \mathrm{~h}$, (c) microstructure after annealing at $760^{\circ} \mathrm{C} / 1 \mathrm{~h}$ and subsequent ageing at $620^{\circ} \mathrm{C} / 1 \mathrm{~h}$.

and Wasserman $(\mathrm{N}-\mathrm{W})$. Electron diffraction performed for the presented microarea indicates the parallelism of $(200)_{\gamma} \|(01 \overline{1})_{\alpha}$ planes characteristic for the Bain relationship. However, due to the deflection of the foil in relation to the electron beam, it cannot be determined which of the crystallographic relationships is present in this area: the Bain, the $\mathrm{K}-\mathrm{S}$ or the $\mathrm{N}-\mathrm{W}$. Figure $4 \mathrm{~b}$ shows the skeletal ferrite morphology. In this case, there is no specified crystallographic relationship. Heat treatment at 400
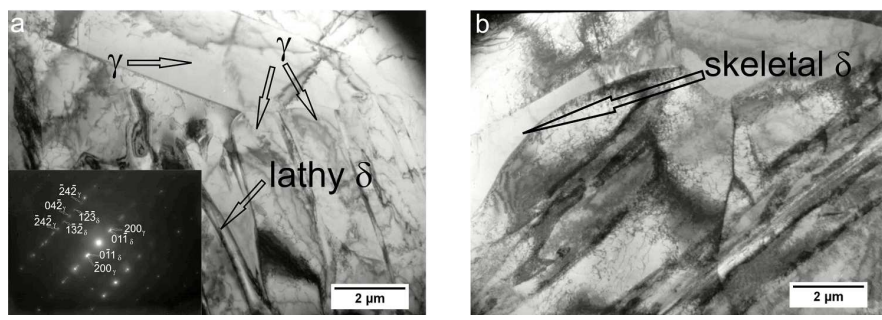

Fig. 3. TEM microstructures of the welds of 17-7PH steel: (a) austenite and lathy ferrite and electron diffraction pattern from $[511] \delta$ and $[012] \gamma$ axes, (b) austenite and skeletal ferrite. 
$620^{\circ} \mathrm{C}$ (samples no. 2-6) does not significantly change the LM microstructures, there are only minor changes of contrast after etching (Fig. 2b). The microstructure contains austenite and delta ferrite. Annealing at $760{ }^{\circ} \mathrm{C}$ for $1 \mathrm{~h}$ after welding (sample 7 ) caused appearance of the tiny coagulated regions at the interphase boundaries. The microstructure consists of austenite partially transformed into martensite and carbides (Fig. 2c). Ageing at 400,450 , and $510^{\circ} \mathrm{C}$ (samples no. 8-10) causes the slight change in the microstructure with respect to the state after annealing at $760^{\circ} \mathrm{C}$ for $1 \mathrm{~h}$ (sample 7 ). Ageing at higher temperatures (samples 11 and 12) intensifies the microstructural features of the martensitic-austenitic structure (Fig. 2b). A few regions of delta ferrite can be also observed. The increase of etching intensity suggests the precipitation of carbides. The carbides were not identified in the present TEM study, however the work [7] shows possible formation of the $\mathrm{M}_{23} \mathrm{C}_{6}$ carbides in the 17-7 PH steel.

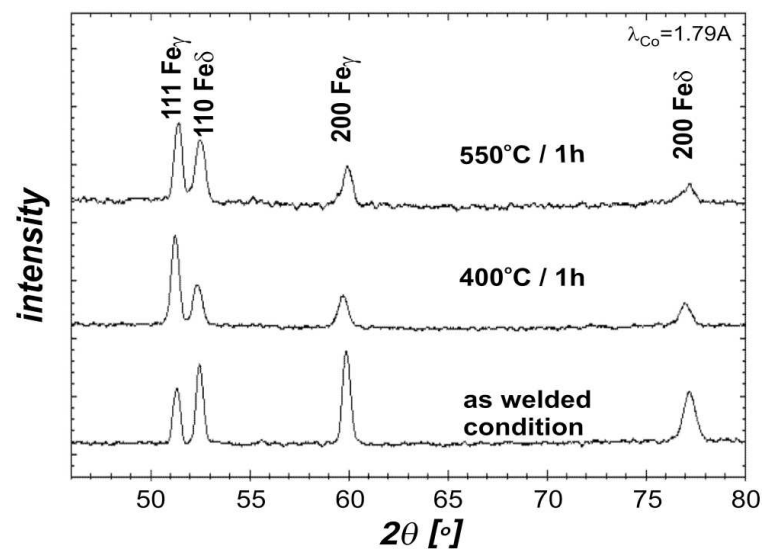

Fig. 4. XRD patterns for welds of 17-7PH steel.

Peak intensity ratios for welded joints.

TABLE III

\begin{tabular}{c|c|c}
\hline \hline Heat treatment & $I_{\gamma 111} / I_{\gamma 200}$ & $I_{\delta 110} / I_{\delta 200}$ \\
\hline reference sample & 2 & 5 \\
\hline as-welded condition & 0.6 & 1 \\
$400^{\circ} \mathrm{C} / 1 \mathrm{~h}$ & 2 & 1.5 \\
$550{ }^{\circ} \mathrm{C} / 1 \mathrm{~h}$ & 1.7 & 2.8
\end{tabular}

X-ray diffraction studies confirmed the presence of austenite and delta ferrite in the as-welded state. The XRD contains a strong peak (200) from austenite and the peak (110) from the ferrite. Moreover, with the increase of the annealing temperature the peak intensity from (111) planes of the austenite increases, and the intensity of the peak from (200) of the $\delta$ ferrite decreases (Fig. 4). Ratios of peak intensity derived from austenite $111_{\gamma} / 200_{\gamma}$ as well as from the ferrite $110_{\delta} / 200_{\delta}$ were calculated and compared to the intensities of the reference sample. The differences in intensities between the theoretical and experimental values indicate stronger texturing of the material (Table III). Figure 5 shows the
ODF for ferrite and for austenite. The ferrite texture in the as-welded state is weak. The strongest component of the texture is the orientation $\{773\}\langle 110\rangle$. In addition, there is a poor fiber orientation $\alpha_{1}=\langle 110\rangle \| \mathrm{RD}$ (rolling direction). After annealing at $400^{\circ} \mathrm{C} / 1 \mathrm{~h}$ there is an evident change of texture. There was strengthening of textures and moving up to a maximum to the orientation $\{001\}\langle 860\rangle$. There is a strong orientation $\{001\}\langle 100\rangle$ and twisted cubic orientation $\{001\}\langle 110\rangle$ fiber $\varepsilon=\langle 001\rangle \| \mathrm{ND}$ (normal direction). Annealing at $550^{\circ} \mathrm{C} / 1 \mathrm{~h}$ did not result in significant changes in the texture of ferrite. The main components were preserved. The texture of austenite of the material in as-welded condition contains a weak component of the fibrous texture $\alpha=\langle 110\rangle \| \mathrm{ND}$ and $\eta=\langle 001\rangle \| \mathrm{RD}$. There is a relatively strong orientation of $\{110\}\langle 112\rangle$ type, whereas no Goss $\{110\}\langle 001\rangle$ texture is observed. After annealing at $400^{\circ} \mathrm{C} / 1 \mathrm{~h}$ the texture of austenite was strengthened, especially fiber $\alpha$ component. Goss orientation was also observed. Maximum orientation corresponds to the $\{110\}\langle 011\rangle$ component. After annealing at $550^{\circ} \mathrm{C} / 1 \mathrm{~h}$ fiber $\alpha$ texture was lenghtened. There is no component of the fiber $\tau=\langle 110\rangle \| \mathrm{TD}$ (transverse direction) in the texture of the austenite in the as-welded state and after anneling.

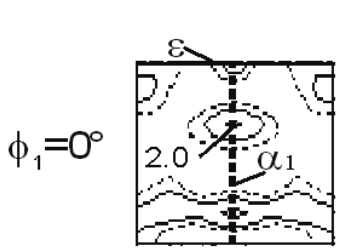

FERRITE

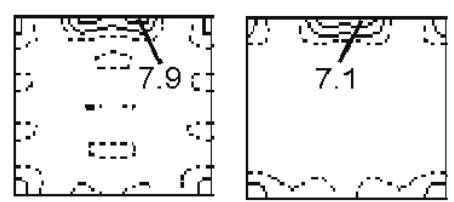

AUSTENITE
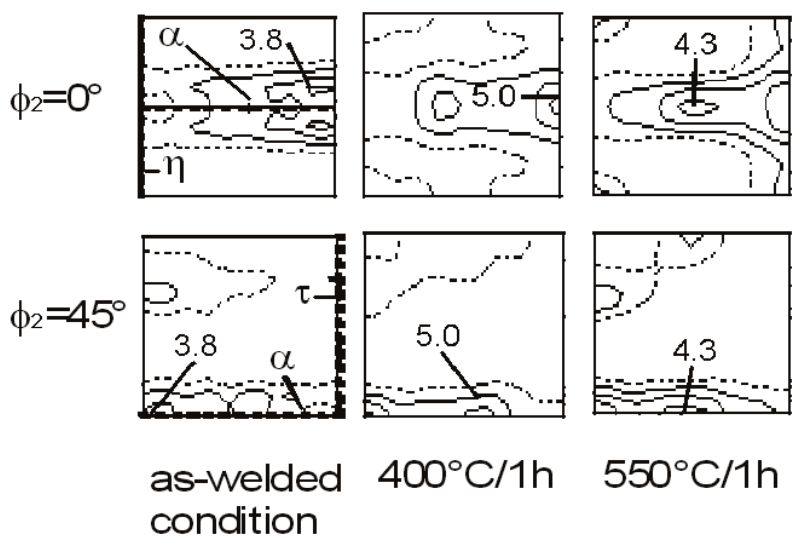

$550^{\circ} \mathrm{C} / 1 \mathrm{~h}$ condition

Fig. 5. Orientation distribution functions in sections $\varphi_{1}=$ const for the $\delta$-phase and in sections $\varphi_{2}=$ const for the $\gamma$-phase in as-welded condition and after heat treatment for welds.

\section{Conclusions}

1. The $17-7 \mathrm{PH}$ steel after welding and ageing in the temperature range $400-620^{\circ} \mathrm{C}$ exhibits an increase of hardness to $480 \mathrm{Hv} 10$. The microstructure after such heat treatment was composed of austenite and $\delta$ ferrite. 
2. Destabilizing at $760^{\circ} \mathrm{C} / 1 \mathrm{~h}$ followed by ageing results firstly in an increase then decrease of hardness. The maximum hardness of $510 \mathrm{HV} 10$ occurs after ageing at $510^{\circ} \mathrm{C}$. The steel microstructure after such treatment consisted of austenite, martensite and $\delta$ ferrite. Higher ageing temperature caused a drop in hardness to $390 \mathrm{Hv10,}$, which indicates the overageing.

3. Analysis of the semi-austenitic steel welds indicates that $\delta$ ferrite occurring in welds has a lathy and skeletal morphology. There are also some areas of the blocky ferrite. There is a parallelism between the austenite and ferrite planes $(200)_{\gamma} \|(01 \overline{1})_{\delta}$ for lathy ferrite and austenite indicating the relationship Bain. No crystallographic relation is observed between the skeletal ferrite and austenite.

4. In as-welded condition austenite was predominating in the texture of the 17-7PH steel. After annealing, ferrite texture is stronger than the fibrous austenite texture.

\section{Acknowledgments}

The research was carried out within the statutory research project no. 11.11.110.299

\section{References}

[1] S. Kou, Welding Metallurgy, Wiley Int., Hoboken (NJ) 2003.

[2] E. Tasak, A. Ziewiec, Weldability of Structural Materials, Vol. 1, JAK, Cracow 2009.

[3] J. Lippold, D. Kotecki, Welding Metallurgy and Weldability of Stainless Steels, Wiley, New Jersey 2005.

[4] AK steel 17-7 PH stainless steel data sheet.

[5] M. Witkowska, A. Zielińska-Lipiec, J. Kowalska, W. Ratuszek, Archiv. Met. Mater. 59, 971 (2014).

[6] X.L. Xu, Z.W. Yu, J. Mater. Process. Technol. 198, 254 (2008).

[7] B. Fakić, D. Ćubela, J. Trends Developm. Machin. Assoc. Technol. 17, 57 (2013).

[8] A. Ziewiec, E. Tasak, M. Witkowska, K. Ziewiec, Archiv. Met. Mater. 58, 613 (2013).

[9] B. Tenerowicz, MSc thesis, AGH, Cracow 2012.

[10] A. Brooks, W.M. Garrison, Weld. Res. Suppl. 8, 280 (1999).

[11] H. Kokawa, T. Kuwana, A. Yamamoto, Weld. Res. Suppl., 92 (1989).

[12] T.J. Headley, J.A. Brooks, Met. Mater. Trans. A 33 , 5 (2002). 